\title{
A NECROSE DA BASE DA FÔLHA DO SISAL
}

\section{J. C. Medina}

O sisal, Agave sisalana Perrine, é uma planta exótica perfeitamente aclimatada em nosso meio. Até agora não se mostrou suscetível a pragas e a única moléstia constatada, realmente causando sérios prejuizos - a "necrose da base da fôlha" - é de natureza fisiológica.

Baseando-se na grande rusticidade da planta, muita terra ruim ou bastante cansada, sem receber qualquer adubação, foi utilizada para a exploração do sisal. Sabe-se, agora, porém, que êste distúrbio fisiológico é motivado por deficiência do solo em potássio e, consequente, desequilíbrio dêste elemento na planta.

Desde que esta moléstia foi assinalada no Estaido, tem sido mais ou menos estudada por diversos especialistas que, entretanto, não chegaram a uma conclusão definitiva sôbre a causa desta alteração do parênquima na base da fôlha. Silberschmidt (11) considera a causa como sendo, provàvelmente, um "virus". Drummond $(4,5$ e 6) que, no início, julgou tratar-se de uma deficiência de potássio do solo, posteriormente assegurou que a causa era devido às baixas temperaturas.

Fora do país, é conhecida desde há muito tempo, em vários centros produtores de sisal. As opiniões sôbre a causa do mal também são bastante variáveis. Uns, consideram o Colletotrichum agaves Cav. como - agente da moléstia; outros, como simples queimaduras provocadas pelo sol incidindo sôbre gotas de orvalho que funcionariam como lentes ; outros, como deficiência de potássio do solo, e, finalmente, outros, como deficiência do solo em elementos químicos e qualidades físicas, ligada a condições adversas de clima.

O autor, suspeitando tratar-se de um estado patológico resultante de uma deficiência de potássio do solo, idêntico ao constatado e estudado por Doop (1, 2 e 3), em Java e Sumatra, instalou, em 1941, um ensaio de adubação com sulfato de potássio, em um antigo viveiro de sisal, em Campinas, onde a moléstia se havia manifestado em carater grave no ano anterior. 
Constatou-se por meio do ensaio a ação efetiva do sulfato de potássio no contrôle dessa moléstia fisiológica. Os resultados obtidos são objeto do presente artigo.

\section{NOME, HISTÓRIA E DISTRIBUIÇÃO GEOGRÁFICA}

Na literatura inglesa, a moléstia é conhecida pelos nomes de "leaf foot disease" e "banding disease". Em alemão, é descrita com o nome de "Umknicken der Blitter". Finalmente, em francês, é designada pelo nome de "collier des feuilles".

Entre nós, ela é geralmente descrita.com o nome de "doença da base da fôlha", sendo mais conhecida, entretanto, pelo nome de "doença do colarinho da tôlha". Todavia, julgamos que a denominação de "necrose da base da fôlha", por nós agora proposta, seria bem aplicada e bastante descritiva, em vista dos sintomàs caraterísticos gue se desenvolvem nas plaritas atacadas.

Na África Orientai ela foi constatada em 1911 e 1912, en Tanga e Dar-es-Salaam (8). Em 1929, Staner e Verplancke (1) relotom um estado patológico semelhante nas plantaçes de Inkisi, no Congo Belqa. Em java, foi observada pela prirreira vez ein 1919, en plantações locali. zadás em solos vermehos cansados $(1,2 \ominus 3)$.

No Brasil scmente foi observada há pouco temoo, talvez porque a cultura de sisal seja relativamente recente $e$ ainda muito limitada.

No Estado de São Paulo, foi constatada pela primeira vez por Drummond (4), em 1930, em plantação de sisal localizada no município de Anápolis. Mais tarde, foi observada em uma cultura mantida rela Prefeitura de Araraquara. Im 1940, o autor (7) a observou, sob uma forma intensa, em plantâs de um aritigo viveiro locálizado na Fazenda Santa Elisa, em Campinas.

No Estado da Baía, ela foi constatada por Rombouts (9), em 1936. plantações existentes no Campo de Policultura do Instituto de Cacau, em Almada.

\section{IMPORTÂNCIA ECONÔMICA}

Atualmente, a moléstia não é de grande importância econômica, dada a limitada cultura existente, mas é de se supor que, com o desenvolvimento que venha a ter a cultura do sisal no Estado, os prejuizos sejam grandes, especialmente se perdurar a rotina de cultivar a planta apenas em terras de segunda categoria.

As plantas afetadas pelo mal, perdem parte das fôlhas, as quais não podem ser mais utilizadas para extração dạ fibra, objeto de sua exploração agrícola.

\section{BREVE REVISÃO DA LITERATURA}

Doop (1, 2 e 3) observou fenômenos de deficiência de potássio em sisal cultivado em solos vermelhos de Pamalvekan e Tjiasin, em Java, que puderam ser controlados mediante uma adubação de sulfato 
de potássio na base de 200 gr por planta. Plantas novas de sisal começaram a apresentar, na idade de 12 a 18 meses, depois de terem crescido normalmente, manchas necróticas na base das fôlhas. $O$ tecido neste lugar se tornava preto e as fôlhas secavam completamente mais tarde.

Drummond (4, 5 e 6) descreve esta moléstia em culturas de Anápolis e Araraquara. Procurou estudar a causa do mal sem chegar a um resultado concludente. No início julgou tratar-se de uma deficiência de potássio dos solos, onde o sisal era cultivado, idêntica à constatada em Java, mas, depois, assegurou que a moléstia estava em estreita relação com as baixas temperaturas. Entretanto, aquêle autor é de opinião que se trata de uma doença de natureza não parasitária.

Morstatt (8) descreve a moléstia da "dobra das fôlhas" na África Oriental, em Tanga e Dar-se-Salaam, onde apareceu pela primeira vez em 1911. Os bordos das fôlhas começam a morrer na zona estreita, próxima da base, tornando-se escuros. Em seguida, a fôlha murcha e dobra-se neste ponto. A moléstia ocorre sòmente em plantas com 18 meses de idade. Constatou ainda que as plantas que haviam recebido uma adubação de cinzas de madeira não eram atingidas pelo mal. Além da deficiência de potássio, o autor também supõe que os solos impermeáveis e pobres em ácido fosfórico são responsáveis pelo aparecimento desta.

Rombouts (9), em 1936, constatou, no Campo de Policultura do Instituto de Cacau da Baía, em Almada, uma moléstia na base das fôlhas do sisal. A julgar pela sua escassa descrição, é idêntica à observada em nosso meio. Segundo o referido autor, lesões necróticas, assemelhando-se a queimaduras, se formam iniciando-se no centro ou nos bordos das fôlhas. Tais lesões aumentam e acabam por cercear a base da fôlha. Esta, freqùentemente, dobra-se no lugar da necrose. Adianta ainda que a moléstia é comum em solos ruins, especialmente em terrenos arenosos, como são os do Campo de Almada. A causa seria a falta de potássio ou de fosfatos no solo.

Staner e Verplancke (10) observaram um estado patológico semelhante em Inkisi, Congo Belga. Concluiram que as manchas presentes na base das fôlhas de sisal eram de origem fisiológica, isto é, devido à fome de potássio das plantas.

Silberschmidt (11) estudando material proveniente da cultura de Anápolis, acha que, provàvelmente, a "leaf foot disease" é uma moléstia de "virus".

\section{SINTOMATOLOGIA}

Uma planta com os sintomas típicos da necrose da base da fôlha, apresenta as fôlhas afetadas dobradas na região das lesões necróticas, de modo que a extremidade toca o solo. Pelas figuras 1 e 2 pode-se observar o aspecto caraterístico de uma planta afetada em comparação com o de uma planta sadia.

O distúrbio se inicia sempre pelo aparecimento de pequenas manchas escuras na parte basal da fôlha, geralmente em ambas as margens ou 
em uma, mais raramente na parte central. As lesões aumentam em tamanho até ocupar tôda a página inferior da fôlha, numa extensão de cêrca de $10 \mathrm{~cm}$, seja pela coalescência de manchas laterais, seja pelo aumento de uma única. Forma-se aí uma larga faixa de tecido preto e sêco, como mostram as figuras 3 e 4 . Quando a área necrótica atinge êste ponto, a fôlha perde a sua turgescência e apresenta uma descoloração geral. Suas margens se enrolam para dentro, $e$, finalmente, dobram-se na região necrótica de modo que a sua extremidade toca o chão. As lesões são deprimidas em ambas as páginas da fôlha.

Constatamos que esta moléstia se manifesta sempre em plantas novas, com cêrca de 12 a 24 meses de idade, nunca antes e nem em plantas já adultas. Também, a julgar pelo que temos observado, ela inicia seu aparecimento em uma plantação sòmente nas fôlhas que atingiram um certo grau de maturidade. Nunca a constatamos em fôlhas novas, que acabam de se destacar do broto central, nem tampouco nas completamente maduras. Atinge sómente aquelas situadas em um ângulo de 45 a 75 graus com a horizontal.

Notamos que, às vezes, se forma, na página inferior da fôlha, no ponto da necrose, uma exudação resinosa. Observamos também que, ao lado de plantas, às vêzes, bem desenvolvidas e bastante afetadas pela moléstia, encontram-se outras menos vigorosas, mas completamente indenes. Finalmente, verificamos que follhas com necrose na fase inicial muitas vêzes se regeneram e permanecem depois sadias.

\section{ENSAIO DE ADUBAÇÃO}

ensaio de adubação para estudo da moléstia, o mais simples possível, obedeceu à distribuição seguinte:

\begin{tabular}{|c|c|c|}
\hline CONTRÔLE & $\mathrm{K}_{2} \mathrm{SO}_{4}$ & $\mathrm{CaCO}_{3}$ \\
\hline $\mathrm{CaCO}_{3}$ & $\mathrm{CONTRÔLE}$ & $\mathrm{K}_{2} \mathrm{CO}_{4}$ \\
\hline $\mathrm{K}_{2} \mathrm{SO}_{4} \cdot$ & $\mathrm{CaCO}_{3}$ & CONTRÔLE \\
\hline
\end{tabular}

Além dos tratamentos com sulfato de potássio e contrôle, acrescentamos também tratamento com carbonato de cálcio, porque, segundo Vageler (12), o sisal requer para seu bom desenvolvimento um solo com pH acima de 7, afirmando categòricamente que, em solos ácidos, a necessidade de cálcio é o fator limitante da produção.

As adubações com potássio foram feitas na base de $100 \mathrm{gr}$ por cova, para a primeira, e de $200 \mathrm{gr}$, em cobertura, para a segunda, realizada um ano depois. As calagens, efetuadas nas mesmas épocas, foram, nas duas adubações, na base de $200 \mathrm{gr}$ por planta. 
Como material de plantio utilizaram-se bulbilhos mantidos em viveiro durante um ano. No transplante procedeu-se a uma escolha rigorosa das mudas, de modo a proporcionar aos tratamentos um material uniforme.

Cada tratamento constou de 10 plantas, dispostas em duas fileiras de 5, observando-se o espaçamento de $1,5 \mathrm{~m}$ entre as plantas e de 2,5 $\mathrm{m}$ eritre as fileiras. Os tratamentos foram separados entre si por uma linha de bordadura, assim como o ensaio do resto do terreno.

\section{ANÁLISES QUIMMICAS}

Como suspeitássemos de que a causa dêste distúrbio fisiológico se devia a uma deficiência de potássio no solo, mandamos efetuar uma análise química de fôlhas afetadas e sadias. Os resultados obtidos, média de duas amostras, estão dispostos na tabela I.

\section{T A B E L A I}

PERCENTAGEM MÉDIA DOS ELEMENTOS DOSADOS EM. FÔLHAS AFE-

TADAS E SADIAS, CALCULADA NA SUBSTÂNCIA SÊCA A 100-110 C.

\begin{tabular}{|c|c|c|c|}
\hline \multirow{2}{*}{ ELEMENTOS } & \multicolumn{2}{|c|}{ FÔLHA AFETADA } & \multirow{2}{*}{$\begin{array}{l}\text { Fôlha sadia de } \\
\text { planta normal }\end{array}$} \\
\hline & $\begin{array}{l}\text { Sòmente a parte } \\
\text { com necrose }\end{array}$ & $\begin{array}{l}\text { Sem a parte } \\
\text { com a necrose }\end{array}$ & \\
\hline $\begin{array}{l}\mathrm{Cinzas} \ldots \ldots \ldots \\
\mathrm{K}_{2} \mathrm{O} \ldots \ldots \ldots \\
\mathrm{CaO} \ldots \ldots \ldots \ldots \\
\mathrm{P}_{2} \mathrm{O}, \ldots \ldots \ldots \\
\mathrm{N} \text { total } \ldots \ldots \ldots \ldots \ldots \\
\mathrm{MgO} \ldots \ldots \ldots \ldots\end{array}$ & $\begin{array}{l}5,334 \\
0,463 \\
3,726 \\
0,163 \\
1,117 \\
0,795\end{array}$ & $\begin{array}{l}8,921 \\
0,736 \\
5,842 \\
0,260 \\
1,501 \\
1,680\end{array}$ & $\begin{array}{l}9,082 \\
0,992 \\
5,689 \\
0,393 \\
1,807 \\
1,485\end{array}$ \\
\hline
\end{tabular}

Segundo Doop (3), o teor de $\mathrm{K}_{2} \mathrm{O}$ nas plantas sadias importa em cêrca de $1,8 \%$ da substância sêca, enquanto nas afetadas êste teor se reduz à metade. As diferenças entre os nossos resultados e os dêste autor se devem possivelmente ao material analisado. Nós apenas analisamos as fôlhas, enquanto Doop utilizou, para análise, a planta tôda. Todavia, os resultados analíticos além de confirmarem a nossa previsão, concernente ao teor em potássio nas fôlhas sadias e afetadas, também mostram as variações existentes em outros elementos nutritivos.

Doop (3), também assegura existir uma relação direta entre o teor em potássio do solo e o distúrbio fisiológico em questão. Esta relação foi evidenciada por numerosas análises efetuadas por Vageler, em ámostras de terra vermelha de Java, coletadas em culturas apresentando plantas atacadas. Vageler determinou que existe nestes solos um valor limite no teor de $\mathrm{K}_{2} \mathrm{O}$ trocável, analíticamente determinado, abaixo do qual 
esta moléstia é inevitável. Segundo o mesmo autor, êste limite parece importar em $140 \mathrm{Kg}$ de $\mathrm{K}_{2} \mathrm{O}$ trocável por hectare, para a camada de $10 \mathrm{~cm}$ superiores do solo.

Uma análise sumária da terra do presente ensaio, executada pela Secção de Química Mineral, sôbre amostra média dos controles, revelou os seguintes resultados:

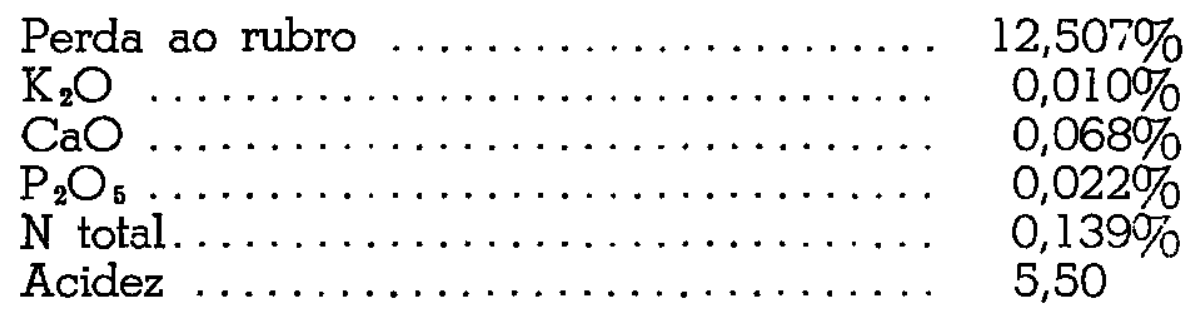

Por esta análise podemos verificar, em relação ao potássio, elemento que mais interessa ao caso, que a terra em questão é muitíssimo fraca. Todavia, êsse processo de tratamento do solo, com ácido clorídrico, extrái um teor de potássio superior ao trocável, que se acha retido pelos colóides do solo e que a planta pode assimilar. Porisso, mandamos efetuar uma determinação dêste, em amostra média de terra coletada dos controles. Segundo a análise, efetuada pela Secção de Agrogeologia, o teor em $\mathrm{K}_{2} \mathrm{O}$ trocável nesta terra foi determinado como sendo de $60 \mathrm{Kg}$ por hectare para os $10 \mathrm{~cm}$ superiores do solo. Naturalmente, não podemos generalizar às nossas condições o valor limite determinado por Vageler, para as terras vermelhas de Java, que tem apenas um valor local. Contudo, para o nosso caso, podemos asseverar que o teor de $\mathrm{K}_{2} \mathrm{O}$ trocável está muito aquem do limite mínimo, o qual, entretanto, não estamos possibilitados a indicar.

\section{RESULTADOS E CONCLUSC̈ES}

Um ano depois de instalado o ensaio, portanto quando as plantas tinham um ano em cultura definitiva, foi efetuado o primeiro protocolo das plantas afetadas, anotando-se então o número de fôlhas sadias e doentes. Os protocolos subsequentes, em número de três, foram realizados bimensalmente. Para simplificar, em lugar de fornecer os dados poŕ planta, apresentamos os dados para cada tratamento. Assim, na tabela II, estão dispostos os números de fôlhas sadias e afetadas e as percentagens destas, para cada tratamento e protocolo.

\section{T A B E L A I I}

NÍMERO DE FÓLHAS SADIAS E AFETADAS E PERCENTAGENS DE FÔLHAS AFETADAS POR TRATAMENTO E PROTOCOLO

\begin{tabular}{l|r|r|r|r|r|r|r|r|r}
\hline \hline \multirow{2}{*}{ PROTOCOLO } & \multicolumn{3}{|c|}{$\mathrm{K}_{2} \mathrm{SO}_{4}$} & \multicolumn{3}{|c|}{$\mathrm{CaCO}_{3}$} & \multicolumn{3}{c}{ CONTRÓLE } \\
\cline { 2 - 9 } & F.S. & F.A. & $\%$ & F.S. & F.A. & $\%$ & F.S. & F.A. & $\%$ \\
\hline & & & - & & & & & & \\
$1.2 / 10 / 42$ & - & - & - & 230 & 29 & 11.2 & 183 & 37 & 16,8 \\
$2.2 / 12 / 42$ & - & - & - & 357 & 54 & 13.1 & 523 & 86 & 14.1 \\
$3.2 / 2 / 43$ & - & - & - & 445 & 65 & 12.7 & 780 & 113 & 12.6 \\
$4.2 / 4 / 43$ & - & - & - & 717 & 119 & 14.2 & 1018 & 186 & 15.4 \\
\hline
\end{tabular}


A seguir, na tabela III, estão dispostos os resultados do número de plantas sadias e afetadas, assim como as percentagens destas, para cada tratamento e protocolo.

T A B E L A I I I

NÚMERO DE PLANTAS SADIAS E AFETADAS E PERCENTAGENS DE PLANTAS AFETADAS POR TRATAMENTO E PROTOCOLO

\begin{tabular}{|c|c|c|c|c|c|c|c|c|c|}
\hline \multirow{2}{*}{ PROTOCOLO } & \multicolumn{3}{|c|}{$\mathrm{K}_{2} \mathrm{SO}_{4}$} & \multicolumn{3}{|c|}{$\mathrm{CaCO}_{3}$} & \multicolumn{3}{|c|}{ CONTRÓLE } \\
\hline & P.S. & P.A. & $\%$ & P.S. & P.A. & $\%$ & P.S. & P.A. & $\%$ \\
\hline $\begin{array}{l}1.2 / 10 / 42 \\
2.2 / 12 / 42 \\
3.2 / 2 / 43 \\
4.2 / 4 / 43\end{array}$ & $\frac{-}{-}$ & - & $\underline{-}$ & $\begin{array}{l}21 \\
18 \\
18 \\
11\end{array}$ & $\begin{array}{r}9 \\
12 \\
12 \\
19\end{array}$ & $\begin{array}{l}30.0 \\
40.0 \\
40.0 \\
63.3\end{array}$ & $\begin{array}{r}23 \\
13 \\
9 \\
4\end{array}$ & $\begin{array}{l}7 \\
17 \\
21 \\
26\end{array}$ & $\begin{array}{l}23.3 \\
56.6 \\
70.0 \\
86.6\end{array}$ \\
\hline
\end{tabular}

Para ilustrar a evolução da moléstia apresentamos; a seguir, dois esquemas do ensaio, para o primeiro e quarto protocolos, nos quais os $x$ representam plantas afetadas e os pontos (.) plantas sadias.

1.0 Protocolo

\begin{tabular}{|c|c|c|}
\hline $\begin{array}{ll}\cdot \\
\dot{\mathrm{x}} \mathrm{x} \\
\dot{x}\end{array}$ & $\begin{array}{ll}\cdot & \cdot \\
\cdot & \cdot \\
\cdot & \cdot \\
\cdot & \cdot \\
\cdot & \cdot\end{array}$ & $\begin{array}{ll}\cdot & \\
\cdot & \\
\cdot & \\
\cdot & \\
\mathrm{x} & \mathrm{x}\end{array}$ \\
\hline $\begin{array}{cc}\mathrm{x} & \mathrm{x} \\
\cdot & \mathrm{x} \\
\cdot & \cdot \\
\mathrm{x} & . \\
. & .\end{array}$ & $\begin{array}{ll}\cdot & \cdot \\
\cdot & \cdot \\
\cdot & \cdot \\
\cdot & \cdot \\
\cdot & \cdot\end{array}$ & $\begin{array}{ll}. & . \\
. & . \\
. & . \\
. & . \\
. & .\end{array}$ \\
\hline & 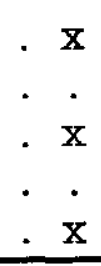 & $\begin{array}{rr}\mathrm{x} & . \\
\cdot & \mathrm{x} \\
\mathrm{x} & \mathrm{x} \\
\cdot & \mathrm{x} \\
. & \\
\end{array}$ \\
\hline
\end{tabular}

4. Protocolo

\begin{tabular}{|c|c|c|}
\hline $\begin{array}{ll}\cdot & \mathrm{x} \\
\cdot & \mathrm{x} \\
\mathrm{x} & \mathrm{x} \\
\mathrm{x} & \mathrm{x} \\
\mathrm{x} & \mathrm{x}\end{array}$ & $\begin{array}{ll}\cdot & . \\
\cdot & . \\
\cdot & . \\
. & . \\
. & .\end{array}$ & $\begin{array}{l}\cdot \\
\dot{0} \\
\dot{\mathrm{x}} \\
\mathrm{x}\end{array}$ \\
\hline $\begin{array}{ll}x & x \\
x & x \\
x & x \\
x & x \\
x & \end{array}$ & $\begin{array}{ll}x & x \\
x & x \\
x & x \\
x & x \\
x & x\end{array}$ & $\begin{array}{ll}\cdot & . \\
\cdot & . \\
\cdot & . \\
\cdot & . \\
. & .\end{array}$ \\
\hline & $\begin{array}{l}\mathrm{x} \mathrm{x} \\
\mathrm{x} \mathrm{x} \\
\cdot \mathrm{x} \\
. \mathrm{x} \\
. \mathrm{x}\end{array}$ & $\begin{array}{ll}x & x \\
x & x \\
x & x \\
. & x \\
x & \end{array}$ \\
\hline
\end{tabular}

Os resultados obtidos com o ensaio demonstram, insofismàvelmente, a ação efetiva do sulfato de potássio no contrôle da moléstia. Do primeiro ao último protocolo das plantas afetadas, nos tratamentos de calagem e contrôle, houve sempre um aumento crescente no número delas. Nos tratamentos com potássio não se constatou a moléstia em nenhuma das 
plantas. Entretanto, nas plantas protocoladas, o número de fôlhas necrosadas aumentou mais ou menos proporcionalmente ao número de fôlhas novas formadas, de modo que houve apenas uma ligeira variação nas percentagens daquelas. Também algumas com início de necrose, conseguiram restabelecer-se oportunamente.

Nos tratamentos com sulfato de potássio, além da ausência de moléstia, as plantas apresentavam um viço exuberante e uma coloração verde mais intensa, em comparação com as dos outros tratamentos, caraterística inconfundível de boa alimentação potássica.

A influência do potássio no desenvolvimento é demonstrada pelos resultados médios de altura de planta para cada tratamento, apresentados na tabela IV.

T A B E L A I V

ALTURA MÉDIA DE PLANTA PARA CADA TRATAMENTO

\begin{tabular}{|c|c|}
\hline TRATAMENTO & $\begin{array}{c}\text { Altura média } \\
\text { das plantas }\end{array}$ \\
\hline $\mathrm{K}_{2} \mathrm{SO}_{4}$ & $83,1 \mathrm{~cm}$. \\
$\mathrm{CaCO}_{3}$ & $75,7 \mathrm{~cm}$. \\
Contrôle & $74,2 \mathrm{~cm}$. \\
\hline
\end{tabular}

Concluindo, podemos afirmar os seguintes tópicos:

1 - A calagem não tem efeito aparente no contrôle da moléstia e no aumento de vigor das plantas.

2 - A acidez não impede o bom desenvolvimento do sisal.

3 - A necrose da base da fôlha é até agora a única moléstia do sisal constatada no Estado, que realmente pode causar danos consideráveis.

4 - Entre nós, o sisal tem sido cultivado em solos deficientes em potássio. Explica-se, assim; a ocorrência da necrose da base das fôlhas em tôdaśs as culturas existentes.

5 - O contrôle pode ser conseguido mediante o plantio do sisal em solos mais ricos em potássio (solos massapés) que os atualmente utilizados, ou pela aplicação, nos solos pobres, de sulfato de potássio na base de 100 a $200 \mathrm{gr}$ anuais por planta.

\section{AGRADECIMENTOS}

Agradecemos a colaboração prestada pelos srs. George Oscar Jensen, que procedeu às análises minerais das fôlhas; Renato Catani, que determinou o potássio trocável ; Ernesto Zink, que traduziu a bibliografia em língua alemã e holandesa, e C. A. Krug, que fez a revisão do sumário em inglês. 


\section{S U M M A R Y}

Sisal (Agave sisalana Perrine) growing in various localities of the State of São Paulo is often heavely damaged by "leaf basal necrose", whose symptoms are identical with the "leaf foot disease" reported from Java, East Africa and Belgian Congo.

The affected leaves show in the initial stages small spots of black, slightly shrivelled tissue on the lower part of the leaf. These gradually spread out. During the later stages the affected leaves bent over at this point. Only approximately mature leaves of plants between 18 to 30 months old are affected.

This disturbance was first observed in Anapolis, Araraquara and Campinas. It was thought to be due to $\mathrm{K}$ deficiency in the soil. In order to prove this a small fertilizer experiment was established at Campinas mainly to study the effect of potassium sulfate as a control measure for this "disease". The experiment also included calcium carbonate and control plots, each treatment being replicated three times.

The results demonstrated that the trouble can be easily controled by the use of potassium sulfate applied in the first year of cultivation (two years atter planting in the nursery). At all plots not treated with $\mathrm{K}$ the typical black spots appeared on the leaves about one year after planting. Considerable damage was caused by this physiological disturbance in all these plots, up to $86,6 \%$ of the plants and $15,4 \%$ of all leaves being damaged at the three control plots 18 months after planting.

The "leaf basal necrose" is until now the single prevalent and destructive "disease" of sisal in the State of São Paulo, where the plant is generally cultivated on $\mathrm{K}$ deficient soils. This explains its occurrence in almost all plantations. To avoid this disturbance sisal should be cultivated on rich soils and fertilised with $\mathrm{K}$ sulfate if grown on poor ones.

\section{LITERATURA CITADA}

1. Doop, J. E. A. den Kalimangelerscheinungen bei sisal und maniok (Kassave) Die Ernährung der Pflanze 33: 108-110. 1937.

2. Doop, J. E. A. den The utilisation of sisal waste in Java and Sumatra. Part III. The East African Agr. Jour. 4: 343-351. 1938-39.

3. Doop, J. E. A. den Groene bemesting, kunstmest in andere factoren in Sisal-en Cassave-productie. Der Bergcultures 9: 1293-1298. 1935.

4. Drummond Gonçalvez, R. Doença do sisal. O Biológico 2: 253-254. 1936.

5. Drummond Gonçalves, R. Manchas da fôlha do sisal. O Biolbgico 5 : 179-180. 1939.

6. Drummond Gonçalvez, R. Doença da fôlha do sisal. O Biolbgico 7: 296-297. 1941.

7. Medina, J. C. Relatório do Serviço de Genética do Instituto Agronômico. 2: 308309. 1940-4 I (Não publicado).

8. Morstatt, H. Blattkrankheiten der Sisalagave. Der Tropenpflanzer 33: 307312. 1930.

9. Rombouts, J. Duas moléstias do henequen (Ägave sisalana). O Campo 8: n. ${ }^{\circ}$ 86: 60. 1937.

10. Staner, P. e G. Verplancke. Un Etat pathologique du sisal au Congo Belge. Bul. Agr. Congo Belge 21: 864-866. 1930.

11. Silberschmidt, K. Doença do sisal. O Biológico 2: 341. 1936.

12. Vagelex, P. $E m$ Grundriss der Tropischen und Subtropischen Bodenkunde, pg. 235, 236, 239. Zweite Auflage, Verlag. f. Ackerbau M.B.H., Berlin. 1938. 




Fig. 1 -.. Planta de sisal afetada pela "necrose da base da fôlha".

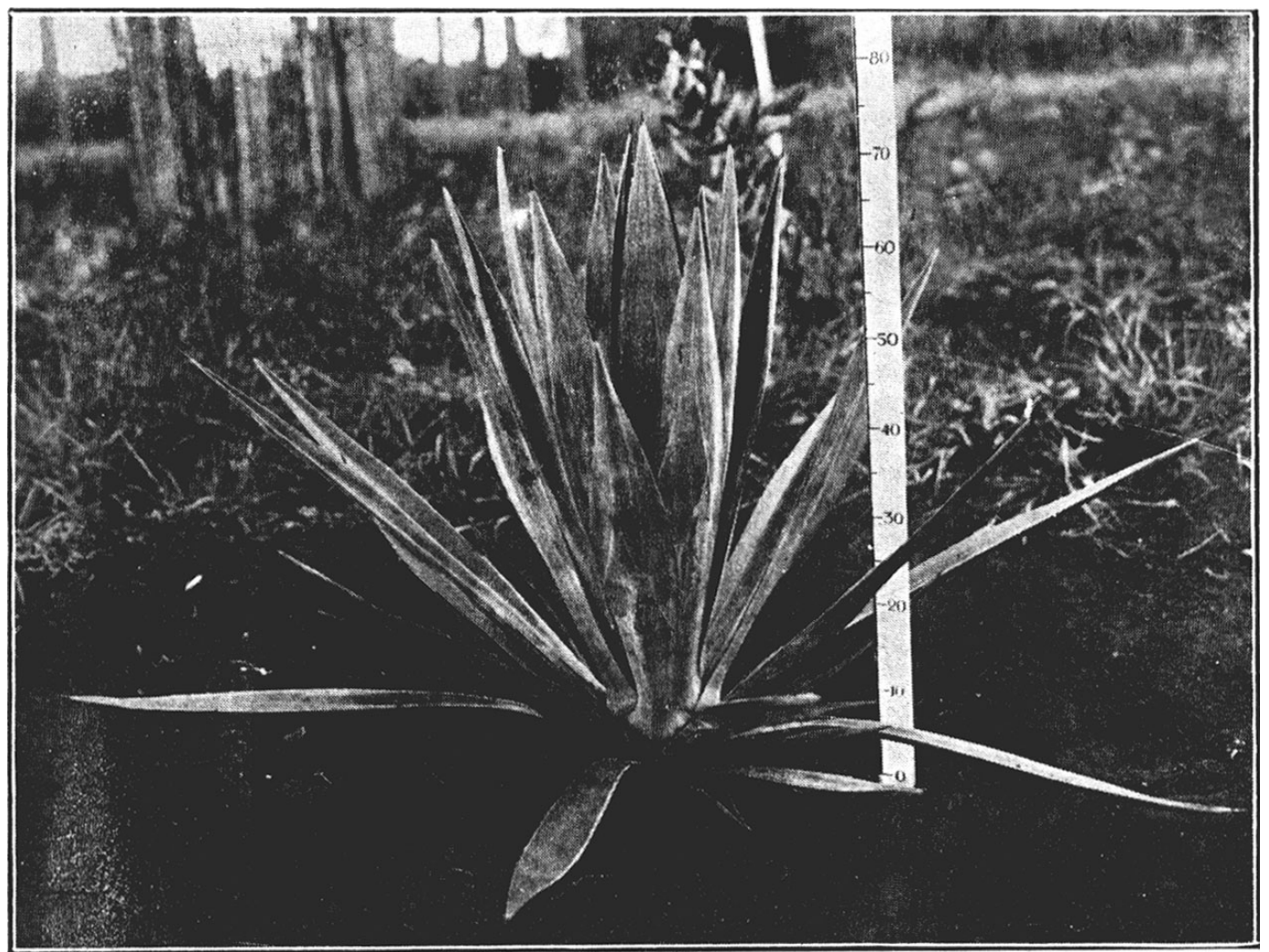

Fig. 2 - Planta normal de sisal 


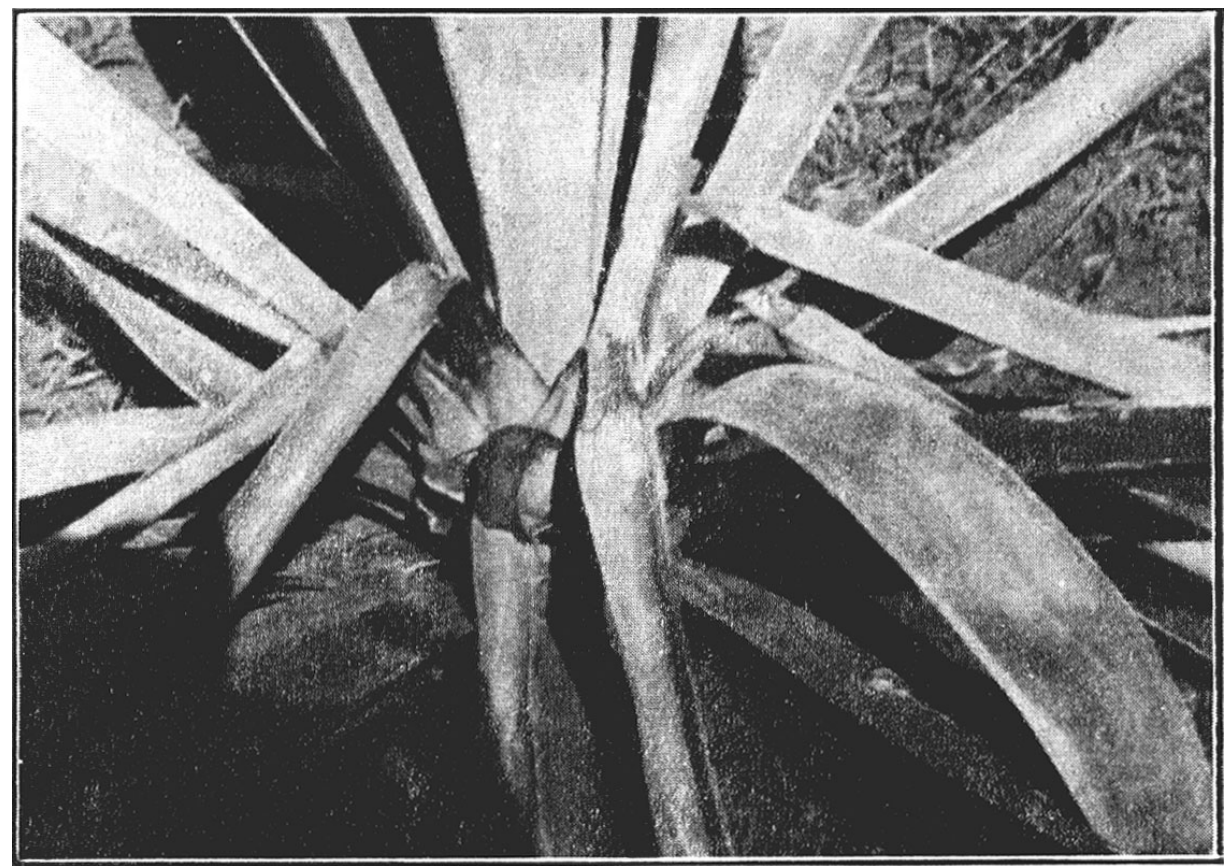

Fig. 3-Planta afelada vista de perto.

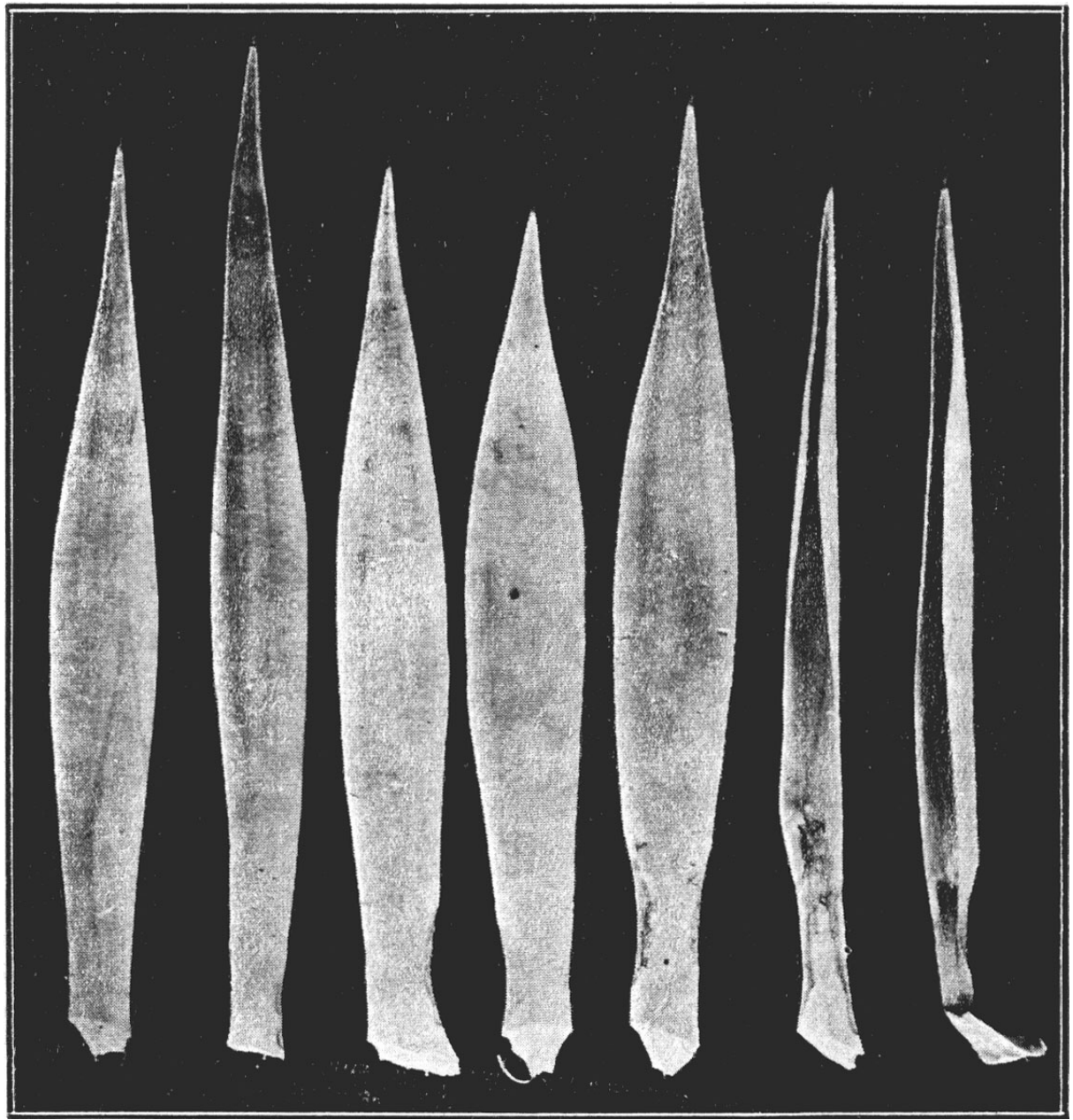

Fig. 4 -.. Série de fôlhas mosirando a evolução da necrose. 